\title{
PERSEPSI PETANI TENTANG PERAN PENYULUH PERTANIAN DALAM PENINGKATAN PENDAPATAN PETANI JAGUNG HIBRIDA
}

\author{
PERCEPTIONS OF FARMERS ON THE ROLE OF AGRICULTURAL \\ EXTENSIONS IN INCREASING INCOME OF HYBRID CORN FARMERS
}

\author{
Novianda Fawaz Khairunnisa*, Zumi Saidah, Hepi Hapsari, Eliana Wulandari \\ Program Studi Agribisnis, Fakultas Pertanian, Universitas Padjadjaran \\ Jl. Raya Bandung-Sumedang KM21, Jatinangor, Sumedang \\ *E-mail: noviandafawaz@gmail.com \\ (Diterima 28-12-2020; Disetujui 14-1-2021)
}

\begin{abstract}
ABSTRAK
Penyuluh pertanian memiliki peran strategis dalam membantu petani untuk meningkatkan usahataninya. Peran penyuluh pertanian antara lain membina petani dalam mengelola usahataninya secara efektif dan efisien sehingga dapat meningkatkan pendapatan petani. Desa Nunuk Baru merupakan salah satu daerah pengembangan komoditas jagung hibrida yang mendapatkan perhatian lebih dalam kegiatan penyuluhan pertanian karena memiliki produktivitas dan luas tanam jagung hibrida yang cukup berpotensi. Penelitian ini bertujuan untuk menganalisis persepsi petani jagung hibrida terhadap peran penyuluh pertanian dan menganalisis pengaruh peran penyuluh pertanian terhadap pendapatan petani jagung hibrida. Desain penelitian yang digunakan yaitu pendekatan kuantitatif dengan metode survey. Responden penelitian ini sebanyak 80 petani jagung. Metode analisis data pada penelitian ini menggunakan analisis deskriptif dengan menggunakan skala sematik diferensial dan analisis regresi linear berganda. Hasil penelitian ini menunjukkan bahwa peran penyuluh pertanian di Desa Nunuk Baru, Kecamatan Maja, Kabupaten Majalengka dikategorikan sangat baik dalam perannya sebagai katalisator, komunikator, konsultan dan organisator; sedangkan sebagai motivator, edukator dan fasilitator dikategorikan baik. Peran penyuluh pertanian tidak berpengaruh nyata terhadap pendapatan petani jagung di Desa Nunuk Baru.
\end{abstract}

Kata kunci: Peran Penyuluh Pertanian, Petani Jagung, Pendapatan

\begin{abstract}
Agricultural extension agents have a strategic role in helping farmers to increase their farming. The role of agricultural extension agents includes fostering farmers in managing their farms effectively and efficiently so that they can increase farmers' income. Nunuk Baru Village is one of the corn commodity development areas that has received more attention in agricultural extension activities because of its potential productivity and planting area for corn. This study aims to identify the role of agricultural instructors for maize farmers and to analyze the influence of the role of agricultural instructors on the income level of maize farmers. The research design used is a quantitative approach with a survey method. The respondents of this research were 80 corn farmers. Methods of data analysis in this study using descriptive analysis using a sematic differential scale and multiple linear regression analysis. The results of this study indicate that the role of agricultural extension agents in Nunuk Baru Village, Maja District, Majalengka Regency is categorized as very good in their role as a catalyst, communicator, consultant and organizer while as a motivator, educator and facilitator are categorized as good. The role of agricultural extension agents has no significant effect on the income of maize farmers in Nunuk Baru Village.
\end{abstract}

Keywords: The Role of Agricultural Extension, Corn Farmers, Income 


\section{PENDAHULUAN}

Jagung (Zea mays L.) merupakan salah satu komoditas subsektor tanaman pangan yang memiliki kedudukan sebagai bahan pangan pokok pengganti beras dan memiliki peran penting bagi perekonomian Indonesia. Menurut (Setiawan, 2008), dalam perspektif ekonomi modern, jagung tidak hanya berfungsi sebagai bahan pangan, tetapi juga merupakan bahan baku utama bagi industri makanan dan pakan ternak (produk jagung). Produksi jagung di Indonesia masih relatif rendah dan masih belum dapat memenuhi kebutuhan konsumen yang cenderung terus meningkat (Tahir \& Suddin, 2017). Oleh karena itu, perlu adanya upaya untuk meningkatkan efisiensi usahatani jagung agar ketersediaan jagung terpenuhi.

Jawa Barat merupakan salah satu provinsi penghasil jagung di Indonesia. Luas panen dan produksi jagung di Jawa Barat pada tahun 2017 masing-masing mencapai produksi jagung Provinsi Jawa Barat sebesar 177.296 ha dan 1.424.928 ton (Kementerian Pertanian Republik Indonesia, 2018). Kabupaten Majalengka sebagai salah satu sentra produksi jagung di Jawa Barat yang memiliki luas panen jagung yang cukup besar yang tersebar di berbagai kecamatan salah satunya yakni
Kecamatan Maja. Berdasarkan data Badan Pusat Statistik Kabupaten Majalengka (2018) luas panen, produksi dan produktivitas jagung di Kecamatan Maja Tahun 2017 masing-masing sebesar 3.392 ha, 26.663 ton dan 7,86 ton/ha. Salah satu daerah di Kecamatan Maja yang menghasilkan jagung adalah Desa Nunuk Baru. Desa Nunuk Baru memiliki kondisi topografi yang cocok untuk komoditas jagung sehingga cukup berpotensi untuk mengembangkan komoditas jagung di daerah tersebut.

Tingkat potensi jagung di Desa Nunuk Baru akan beriringan dengan besarnya produktivitas usahatani yang pada akhirya berpengaruh terhadap pendapatan petani. Salah satu faktor yang berpengaruh terhadap produktivitas usahatani adalah kualitas sumber daya petani karena petani merupakan aktor yang berhubungan langsung terhadap usahataninya. Oleh sebab itu, perlu adanya upaya pemerintah untuk meningkatkan kualitas petani melalui pemberdayaan masyarakat petani seperti penyuluhan pertanian.

Penyuluhan adalah proses pendidikan yang bertujuan untuk mengubah kesadaran dan perilaku (pengetahuan, sikap, dan keterampilan) manusia ke arah yang lebih baik sehingga 
mereka menjadi berdaya dan dapat mencapai kehidupan yang lebih baik dan sejahtera (Muljono, 2007). Penyuluhan pertanian merupakan bentuk perpanjangan tangan antara pemerintah dengan petani yang dilaksanakan oleh seorang penyuluh pertanian dalam rangka meningkatkan hasil produksi dan pendapatan petani. Menurut $\mathrm{M}$ et al, (2019), peran penyuluh pertanian sangat dibutuhkan untuk membimbing petani dalam meningkatkan keterampilan petani sehingga diharapkan adopsi petani terhadap teknologi pertanian tinggi sehingga dapat meningkatkan hasil produksi petani serta meningkatkan kesejahteraan petani dan keluarganya.

Keberhasilan program penyuluhan sangat dipengaruhi oleh kinerja penyuluh pertanian yang sesuai dengan kebutuhan petani. Petani merupakan subjek atau aktor utama yang harus diprioritaskan karena sebagai penerima manfaat dari program penyuluhan pertanian. Persepsi petani terhadap peran penyuluh merupakan faktor yang menentukan partisipasi petani dalam kegiatan penyuluhan (Krisnawati et al, 2013)

Oleh karena itu, perlu dilakukan penelitian tentang persepsi petani jagung hibrida terhadap peran penyuluh pertanian di Desa Nunuk Baru,
Kecamatan Maja, Kabupaten Majalengka. Berdasarkan uraian tersebut, maka tujuan penelitian ini adalah (1) menganalisis persepsi petani jagung hibrida terhadap peran penyuluh pertanian dan (2) menganalisis pengaruh peran penyuluh pertanian terhadap pendapatan petani jagung hibrida.

\section{METODE PENELITIAN}

Penelitian ini dilakukan di Desa Nunuk Baru, Kecamatan Maja, Kabupaten Majalengka Provinsi Jawa Barat. Pemilihan lokasi didasarkan bahwa Desa Nunuk Baru merupakan salah satu daerah dengan produksi jagung hibrida terbanyak yang ada di Kecamatan Maja dan daerah yang mendapatkan perhatian lebih dalam kegiatan penyuluhan pertanian karena produktivitas dan luas lahan cukup berpotensi. Objek penelitian ini adalah peran penyuluh pertanian dan faktor-faktor yang mempengaruhi pendapatan petani jagung hibrida. Metode pengambilan sampel dilakukan dengan menggunakan teknik probabbility sampling dengan metode simple random sampling. Penentuan jumlah sampel dengan menggunakan rumus Slovin sehingga diperoleh total responden 80 petani jagung hibrida. Desain penelitian yang digunakan yaitu pendekatan 
kuantitatif dengan metode survei. Instrumen yang digunakan berupa kuesioner yang terlebih dahulu dilakukan uji validitas dan reliabilitas

Metode analisis data pada penelitian ini menggunakan analisis deskriptif, analisis pendapatan usahatani dan analisis regresi linear berganda. Analisis deskriptif dilakukan untuk menganalisis persepsi petani jagung hibrida terhadap peran penyuluh pertanian di Desa Nunuk Baru. Penilaian peran penyuluh pertanian dilakukan berdasarkan tujuh peran penyuluh pertanian, yakni: motivator, edukator, katalisator, komunikator, konsultan, fasilitator dan organisator. Variabel pengamatan dilakukan klasifikasi dengan metode skor yang dipilih oleh petani responden. Penilaian tersebut akan diberi skor pada setiap variabel yang dihitung menggunakan skala diferensial sematik (Simamora, 2005) yang dapat dilihat pada Tabel 1.

Tabel 1. Kategori Peran Penyuluh Pertanian

\begin{tabular}{ccc}
\hline No & Interval Kelas & $\begin{array}{c}\text { Tingkat Peran } \\
\text { Penyuluh Pertanian }\end{array}$ \\
\hline 1 & $3,0-5,4$ & Sangat tidak baik \\
2 & $5,5-7,9$ & Tidak baik \\
3 & $8,0-10,4$ & Kurang baik \\
4 & $10,5-12,9$ & Baik \\
5 & $13,0-15,4$ & Sangat baik \\
\hline
\end{tabular}

Sementara itu, menurut Suratiyah (2006), analisis pendapatan usahatani dihitung menggunakan rumus sebagai berikut:

$$
\mathrm{I}=\mathrm{TR}-\mathrm{TC}
$$

Keterangan:

$\mathrm{I}=$ Income (pendapatan), $\mathrm{TR}=$ Total Revenue (penerimaan total), $\mathrm{TC}=$ Total Cost (biaya total)

Berdasarkan analisis pendapatan tersebut maka dapat diperoleh rasio $\mathrm{R} / \mathrm{C}$ dengan rumus sebagai berikut:

$$
\mathrm{R} / \mathrm{C}=\frac{\text { Penerimaan Total }}{\text { Biaya Total }}
$$

Ada tiga kriteria dalam perhitungannya, yaitu:

a) Apabila $\mathrm{R} / \mathrm{C}>1$ artinya usahatani tersebut menguntungkan

b) Apabila $\mathrm{R} / \mathrm{C}=1$ artinya usahatani tersebut impas

c) Apabila $\mathrm{R} / \mathrm{C}<1$ artinya usahatani tersebut rugi

Selanjutnya menganalisis pengaruh peran penyuluh pertanian terhadap pendapatan petani jagung hibrida dengan dengan menggunakan aplikasi STATA versi 14. Sebelum data diolah menggunakan uji regresi linear berganda, dilakukan pengujian data terlebih dahulu yaitu uji asumsi klasik untuk memenuhi persyaratan Best Linear Unbiased Estimator (BLUE) mengingat ini merupakan data cross section. Model yang digunakan adalah sebagai berikut: 
$\mathrm{Y}=\alpha+\beta_{1} \mathrm{X}_{1}+\beta_{2} \mathrm{X}_{2}+\beta_{3} \mathrm{X}_{3}+\beta_{4} \mathrm{X}_{4}+$ $\beta_{5} \mathrm{X}_{5}+\beta_{6} \mathrm{X}_{6}+\beta_{7} \mathrm{X}_{7}+\varepsilon$

Keterangan:

$\mathrm{Y}=$ Pendapatan Usahatani Jagung $(\mathrm{kg}) ; \alpha$ $=$ Nilai konstanta (intersept); $\beta=$ Koefisien arah regresi (slope); $\mathrm{X}_{1}=$ Luas lahan (hektar); $\mathrm{X}_{2}=$ Produksi jagung $(\mathrm{kg}) ; \mathrm{X}_{3}=$ Biaya benih $(\mathrm{Rp}) ; \mathrm{X}_{4}=$ Biaya pupuk (Rp); $\mathrm{X}_{5}=$ Biaya pestisida $(\mathrm{Rp})$; $\mathrm{X}_{6}=$ Biaya tenaga kerja $(\mathrm{Rp}) ; \mathrm{X}_{7}=$ Peran penyuluh pertanian (skor); $\varepsilon=$ Error

\section{HASIL DAN PEMBAHASAN}

\section{Persepsi Petani Hibrida terhadap}

\section{Penyuluh Pertanian}

Petani sebagai pelaku utama dalam kegiatan usahataninya yang merupakan modal utama penggerak pembangunan pertanian di Indonesia. Oleh karena itu, kualitas sumber daya manusia petani perlu ditingkatkan melalui penyuluhan pertanian yang didampingi oleh seorang penyuluh. Peran penyuluh dalam penelitian ini dilihat dari 7 aspek yakni motivator, edukator, katalisator, komunikator, konsultan, fasilitator dan organisator yang merupakan hasil gabungan dari penelitian Rahmawati et al. (2019) dan Resicha (2016). Peran penyuluh tersebut diukur berdasarkan persepsi petani responden. Berikut ini merupakan hasil mayoritas penilaian petani terhadap peran penyuluh pertanian yang dapat dilihat pada Tabel 2 .

Tabel 2. Persepsi Mayoritas Petani Hibrida terhadap Peran Penyuluh Pertanian di Desa Nunuk Baru

\begin{tabular}{lcccc}
\hline \multicolumn{1}{c}{ Peran Penyuluh } & Interval Kelas & Jumlah (orang) & Persentase (\%) & Tingkat Peranan \\
\hline Motivator & $10,5-12,9$ & 43 & 53,75 & Baik \\
\hline Edukator & $10,5-12,9$ & 40 & 50 & Baik \\
\hline Katalisator & $13,0-15,4$ & 45 & 56,25 & Sangat Baik \\
\hline \multirow{2}{*}{ Komunikator } & $10,5-12,9$ & 39 & 48,75 & Baik \\
\cline { 2 - 5 } & $13,0-15,4$ & 39 & 48,75 & Sangat Baik \\
\hline Kosultan & $13,0-15,4$ & 51 & 63,75 & Sangat Baik \\
\hline Fasilitator & $10,5-12,9$ & 35 & 43,75 & Baik \\
\hline Organisator & $13,0-15,4$ & 59 & 73,75 & Sangat Baik \\
\hline
\end{tabular}

Berdasarkan Tabel 3, dapat disimpulkan bahwa mayoritas persepsi petani jagung terhadap peran penyuluh pertanian sebagai motivator masuk kedalam kategori baik. Menurut petani responden, penyuluh pertanian telah menjalankan perannya sebagai mativator yaitu membantu petani mengarahkan usahatani sesuai anjuran dari Dinas Pertanian, mendorong untuk mengembangkan usahatani yang lebih menguntungkan dan mendorong petani untuk menerapkan teknologi pertanian dalam usahatani. Hal ini sejalan dengan penelitian yang dilakukan oleh Rahmawati et al. (2019) yang 
menyimpulkan bahwa peran kinerja penyuluh pertanian sangat baik dalam memotivasi petani, mengarahkan usahatani dan memotivasi petani meningkatkan hasil produksi tanaman jagung melalui program intensifikasi jagung.

Persepsi mayoritas petani jagung terhadap peran penyuluh pertanian sebagai edukator masuk kedalam kategori baik. Menurut petani responden, penyuluh pertanian telah menjalankan perannya sebagai edukator yaitu menambah pengetahuan petani dalam mengelola usahatani yang tepat. Selain itu, penyuluh juga memberikan pelatihan untuk meningkatkan keterampilan petani seperti penggunaan sarana input pertanian, teknologi pertanian dan cara mengendalikan hama penyakit tanaman. Menurut Rahmawati et al. (2019) adopsi petani terhadap inovasi baru membutuhkan proses pembelajaran yang efektif dan efisien serta ditunjang oleh materi, metode dan media penyuluhan yang dapat dipahami oleh petani.

Persepsi mayoritas petani jagung terhadap peran penyuluh pertanian sebagai katalisator masuk kedalam kategori sangat baik. Terdapat tiga indikator untuk mengukur peran penyuluh sebagai katalisator antara lain menyampaikan aspirasi petani, menyampaikan kebijakan sektor pertanian kepada petani dan menjadi penghubung antara petani dengan lembaga pemerintah. Peranan penyuluh di dalam suatu program sangat berperan penting guna sebagai jembatan penghubung antara pemerintah serta menyampaikan umpan balik dari masyarakat yang bertujuan membantu masyarakat memperbaiki mutu hidup dan kesejahteraannya (Padillah et al., 2018)

Persepsi mayoritas petani jagung terhadap peran penyuluh pertanian sebagai komunikator masuk kedalam kategori baik cenderung sangat baik. Peran penyuluh sebagai komunikator terdiri dari tiga indikator, yaitu kemampuan penyuluh dalam berkomunikasi kepada petani, membantu mempercepat arus informasi baik antar petani dan petani dengan pemerintah serta membantu petani dalam mengambil keputusan. Penelitian Zulfikar et al. (2018) menyatakan bahwa penyuluh mampu merencanakan kegiatan pembelajaran yang menarik dan mudah dipahami dan penyuluh mampu membangun dinamika kelompok melalui pemilihan media yang digunakan.

Persepsi mayoritas petani jagung terhadap peran penyuluh pertanian 
sebagai konsultan masuk kedalam kategori sangat baik. Hal tersebut dibuktikan dengan pernyataan petani responden yang menyatakan bahwa penyuluh telah memberikan nasihat kepada petani apabila usahatani yang dilakukan oleh petani masih kurang tepat. Penyuluh juga membantu petani dalam menmecahkan permasalahan usahatani serta memberikan informasi kepada petani mengenai usahatani yang cocok dan sesuai dengan kondisi musim, tanah dan hama di daerah penelitian yang akan memberikan keuntungan maksimal bagi petani. Menurut Sadono (2008), penyuluhan pertanian mempunyai peran untuk membantu petani agar dapat menolong dirinya untuk mengatasi permasalahan yang dihadapinya secara baik dan memuaskan sehingga meningkat derajat kehidupannya.

Persepsi mayoritas petani jagung terhadap peran penyuluh pertanian sebagai fasilitator adalah baik. Peran penyuluh sebagai fasilitator terdiri dari tiga indikator, yaitu memfasilitasi kegiatan belajar mengajar usahatani kepada petani, memberikan akses petani kepada pihak permodalan dan pemasaran. Berdasarkan hasil wawancara dengan petani, penyuluh pertanian telah menginformasikan serta menghubungkan petani dengan program-program permodalan dari pemerintah dan bank swasta. Menurut petani, peran penyuluh dalam memfasilitasi petani dalam akses pemasaran hasil produksi usahatani masih kurang baik karena penyuluh pertanian belum mampu memutus mata rantai tengkulak/bandar desa dan belum menghubungkan petani dengan pelaku usaha di bidang agribisnis. Hal ini sejalan dengan penelitian Listiana et al. (2018), secara umum tingkat kemampuan penyuluh dalam memfasilitasi petani terhadap akses sumber daya dan teknologi berada pada kategori sedang cenderung rendah.

Persepsi mayoritas petani jagung terhadap peran penyuluh pertanian sebagai organisator masuk kedalam kategori sangat baik. Peran penyuluh sebagai organisator antara lain mengordinir kegiatan usahatani agar lebih terarah mulai dari penggunaan sarana input pertanian hingga panen. Selain itu, penyuluh juga menumbuhkan wahana kerjasama petani dalam kelompok tani dan mengarahkan petani dalam memilih usahatani yang beresiko kecil mengalami gagal panen dan yang lebih menguntungkan. Penelitian Lusiana et al. (2018), penyuluh sebagai organisator menyangkut pembentukan 
suatu kelompok-kelompok tani dan pengembangan kelompok tani.

\section{Pengaruh Peran Penyuluhan terhadap}

Tingkat Pendapatan Petani Jagung

Hibrida

Pendapatan petani diperoleh dari selisih antara penerimaan usahatani dengan seluruh biaya produksi yang dikeluarkan petani selama satu kali musim tanam. Hasil perhitungan rata-rata biaya produksi, penerimaan dan pendapatan petani jagung hibrida di Desa Nunuk Baru untuk rata-rata luas lahan sebesar 0,858 ha dalam satu kali musim tanam, dapat dilihat pada Tabel 3.

Tabel 3. Rata-rata biaya produksi, penerimaan dan pendapatan petani jagung hibrida di Desa Nunuk Baru

\begin{tabular}{lc}
\hline \multicolumn{1}{c}{ Komponen } & Jumlah (Rp) \\
\hline Total Penerimaan (TR) & $14.945 .687,5$ \\
Biaya Produksi: & \\
Total Biaya Tetap & 628.711 \\
Total Biaya Variabel & $6.298 .931,25$ \\
Total Biaya (TC) & $6.927 .642,25$ \\
Pendapatan (I) & $8.018 .045,25$ \\
R/C & 2,16 \\
\hline
\end{tabular}

Berdasarkan Tabel 3, dapat diketahui bahwa rata-rata pendapatan jagung hibrida di daerah penelitian adalah Rp8.018.045,25/0,858ha/MT. Dari data tersebut terlihat bahwa total penerimaan lebih besar dari total biaya yang dikeluarkan artinya penerimaan petani dapat menutupi semua biaya yang dikeluarkan dalam proses produksi usahatani jagung di daerah penelitian dan usahatani jagung ini merupakan usahatani yang menjanjikan untuk pendapatan petani jagung di daerah penelitian. Hasil perhitungan menunjukkan bahwa ratarata $\mathrm{R} / \mathrm{C}$ sebesar 2,16 yang menunjukkan bahwa setiap penambahan biaya satu rupiah akan mendapatkan penerimaan sebesar 2,16 rupiah. Rata-rata R/C tersebut bernilai $>1$ yang artinya usahatani jagung hibrida di Desa Nunuk Baru layak dan menguntungkan untuk diusahakan.

Selanjutnya, menganalisis pengaruh peran penyuluh pertanian terhadap tingkat pendapatan petani hibrida di Desa Nunuk Baru. Faktor-faktor penduga yang diidentifikasi dalam penelitian ini yaitu jumlah produksi, luas lahan, biaya benih, biaya pupuk, biaya pestisida, biaya tenaga kerja dan peran penyuluh pertanian. Adapun hasil analisis dapat dilihat pada Tabel 4.

Berdasarkan hasil analisis yang dilakukan diperoleh persamaan regresi hasil penelitian adalah $\mathrm{Y}=1.225 .171+$ $522.218,1 \mathrm{X}_{1}+2.916,52 \mathrm{X}_{2}-1,14 \mathrm{X}_{3}-$ $0,98 \mathrm{X}_{4}-0,85 \mathrm{X}_{5}-1,04 \mathrm{X}_{6}-10.728,57 \mathrm{X}_{7}$ $+\varepsilon$. Dapat diketahui bahwa peran penyuluh pertanian tidak berpengaruh signifikan terhadap pendapatan petani 
jagung di Desa Nunuk Baru. Sementara itu, variabel yang berpengaruh signifikan antara lain produksi jagung, biaya benih, biaya pupuk, biaya pestisida dan biaya tenaga kerja.

Tabel 4. Hasil Analisis Regresi Linear Berganda Faktor-faktor Pendapatan Petani Jagung Hibrida di Desa Nunuk Baru, Kecamatan Maja, Kabupaten Majalengka

\begin{tabular}{lcccc}
\hline \multicolumn{1}{c}{ Variabel } & $\begin{array}{c}\text { Koefisien } \\
\text { Regresi }\end{array}$ & Standar Error & t-hitung & p-value \\
\hline Luas Lahan (X1) & $522.218,1$ & $510.735,4$ & 1,02 & $0,310^{\text {ns }}$ \\
Produksi Jagung (X2) & $2.916,52$ & 90,62496 & 32,18 & $0,000^{* *}$ \\
Biaya Benih (X3) & $-1,14035$ & 0,3934456 & $-2,90$ & $0,005^{* *}$ \\
Biaya Pupuk (X4) & $-0,9852454$ & 0,0923743 & $-10,67$ & $0,000^{* *}$ \\
Biaya Pestisida (X5) & $-0,8544787$ & 0,4833845 & $-1,77$ & $0,081^{*}$ \\
Biaya Tenaga Kerja (X6) & $-1,037348$ & 0,089735 & $-11,56$ & $0,000^{* *}$ \\
Peran Penyuluh Pertanian (X7) & $-10.728,57$ & $16.744,91$ & $-0,64$ & $0,524^{\text {ns }}$ \\
\hline Konstanta & 1.225 .171 & 1.476 .483 & 0,83 & 0,409 \\
\hline F Hitung & & & 849,94 \\
\hline Sigh F & & & 0,0000 \\
\hline Adjusted R & & & \\
\hline $\mathrm{N}$ & & & \\
\hline
\end{tabular}

Keterangan : $*$ signifikan pada taraf 0,$01 ; * *=$ signifikan pada taraf 0,$5 ; \mathrm{ns}=$ tidak signifikan

Produksi jagung $\left(\mathrm{X}_{2}\right)$ memiliki hubungan yang positif atau searah dengan pendapatan petani jagung. Setiap peningkatan luas lahan sebesar 1\% dengan menganggap faktor lainnya tetap (ceteris paribus) maka jumlah produksi jagung akan mengalami peningkatan sebesar 2.916,52. Hal ini sesuai dengan penelitian Apriliana \& Mustadjab (2016) tentang analisis faktor-faktor yang mempengaruhi pengambilan keputusan petani dalam menggunakan benih hibrida pada usahatani jagung di Desa Patokpicis, Kecamatan Wajak, Kabupaten Malang yang menyatakan bahwa hasil produksi berpengaruh positif terhadap pendapatan usahatani jagung.

Biaya benih $\left(\mathrm{X}_{3}\right)$ memiliki hubungan yang negatif terhadap pendapatan petani jagung. Setiap peningkatan biaya benih sebesar $1 \%$ dengan menganggap faktor lainnya tetap (ceteris paribus) maka pendapatan petani jagung akan mengalami penurunan sebesar 1,14. Hal tersebut sesuai dengan penelitian Santoso \& Sudarmadji (2013) tentang faktor-faktor yang mempengaruhi produksi jagung di Kabupaten Sumenep yang menyatakan bahwa adanya pengaruh biaya benih secara positif terhadap tingkat pendapatan petani jagung di Desa Gedang-gedang.

Biaya pupuk $\left(\mathrm{X}_{4}\right)$ memiliki hubungan yang negatif dengan pendapatan petani jagung. Setiap peningkatan biaya pupuk sebesar $1 \%$ dengan menganggap faktor lainnya tetap (ceteris paribus) maka pendapatan petani 
jagung akan mengalami penurunan sebesar 0,98 . Hal tersebut sejalan dengan penelitian Apriliana \& Mustadjab (2016) yang menyatakan bahwa biaya pupuk berpengaruh negatif terhadap pendapatan usahatani jagung.

Biaya pestisida $\left(\mathrm{X}_{5}\right)$ memiliki hubungan yang negatif dengan pendapatan petani jagung. Setiap peningkatan biaya pestisida sebesar $1 \%$ dengan menganggap faktor lainnya tetap (ceteris paribus) maka pendapatan petani jagung akan mengalami penurunan sebesar 0,85 . Hal tersebut sesuai dengan penelitian Santoso \& Sudarmadji (2013) tentang faktor-faktor yang mempengaruhi produksi jagung di Kabupaten Sumenep yang menyatakan bahwa terdapat pengaruh secara negatif antara biaya pestisida terhadap tingkat pendapatan petani jagung.

Biaya tenaga kerja $\left(\mathrm{X}_{6}\right)$ memiliki hubungan yang negatif dengan pendapatan petani jagung. Setiap peningkatan biaya pestisida sebesar $1 \%$ dengan menganggap faktor lainnya tetap (ceteris paribus) maka pendapatan petani jagung akan mengalami penurunan sebesar 0,85. Hal ini sejalan dengan penelitian yang dilakukan oleh Joan et al. (2018) tentang analisis fungsi pendapatan usahatani jagung arjuna di Desa Mulyo
Agung, Kecamatan Dau, Kabupaten Malang yang menyatakan bahwa variabel upah tenaga kerja berpengaruh negatif terhadap pendapatan usahatani jagung.

Peran penyuluh pertanian $\left(\mathrm{X}_{7}\right)$ tidak berpengaruh signifikan terhadap pendapatan petani jagung. Berdasarkan informasi yang didapat dari hasil wawancara, sebagian besar petani di Desa Nunuk Baru merasakan peran penyuluh pertanian sudah berperan baik dalam mendampingi, menambah pengetahuan, keterampilan dan membantu memecahkan masalah yang dihadapi oleh petani. Salah satu faktor yang menyebabkan tidak signifikannya peran penyuluh pertanian terhadap pendapatan petani adalah kurangnya kepercayaan petani kepada penyuluh pertanian. Menurut petugas penyuluh pertanian, kebanyakan petani tidak mau menerapkan apa yang diarahkan oleh penyuluh sebelum ada bukti nyata. Selain itu, penyuluh belum mampu memutus mata rantai bandar atau tengkulak sehingga penerimaan yang diperoleh petani kurang maksimum. Hal ini menunjukkan bahwa peran penyuluh belum optimal dalam membantu petani meningkatkan pendapatannya jagung.

Hasil penelitian ini berbeda dengan penelitian Inten et al. (2017) tentang 
peranan penyuluh pertanian dalam peningkatan pendapatan petani komoditas padi di Kecamatan Tanjungselor, Kabupaten Bulungan, Kalimantan Utara yang menyatakan bahwa penyuluh dapat memberikan pengaruh terhadap tingkat pendapatan petani. Penelitian Lusiana et al. (2018) menyatakan bahwa peran penyuluh sebagai pembimbing dan fasilitator berpengaruh terhadap pendapatan petani sedangkan sebagai organisator dan fasilitator tidak berpengaruh terhadap pendapatan petani.

\section{KESIMPULAN DAN SARAN}

\section{Kesimpulan}

Berdasarkan hasil penelitian yang telah dilakukan, dapat disimpulkan bahwa peran penyuluh pertanian bagi petani jagung hibrida di Desa Nunuk Baru, Kecamatan Maja, Kabupaten Majalengka dalam menjalankan tugasnya sebagai katalisator, komunikator, konsultan dan organisator dikategorikan sangat baik. Sedangkan penilaian petani terhadap peran penyuluh pertanian sebagai motivator, edukator dan fasilitator dikategorikan baik. Berdasarkan hasil uji regresi yang dilakukan menunjukkan bahwa peran penyuluh pertanian tidak berpengaruh signifikan terhadap pendapatan petani jagung hibrida di Desa Nunuk Baru. Hal ini terjadi salah satunya karena petani masih cenderung melakukan kebiasaankebiasaannya sendiri dalam mengelola usahatani jagung.

\section{Saran}

Dari penelitian ini disarankan agar penyuluh pertanian sebaiknya melakukan pendampingan, monitoring secara intensif, meningkatkan akses petani terhadap permodalan dan pemasaran serta melakukan pendekatan kepada petani agar petani mau menerapkan yang sudah disampaikan oleh penyuluh dalam rangka meningkatkan produksi dan pendapatan usahatani. Diharapkan petani lebih berperan aktif dalam kegiatan penyuluhan dan mengikuti anjuran yang diberikan oleh petugas penyuluh pertanian.

\section{DAFTAR PUSTAKA}

Apriliana, M., \& Mustadjab, M. (2016). Analisis Faktor-Faktor yang Mempengaruhi Pengambilan Keputusan Petani Dalam Menggunakan Benih Hibrida Pada Usahatani Jagung (Studi Kasus di Desa Patokpicis, Kecamatan Wajak, Kabupaten Malang). Jurnal Habitat, 27(1), 7-13.

Badan Pusat Statistik Kabupaten Majalengka. (2018). Luas Panen, Produksi dan Produktivitas Tanaman Pangan dan Palawija Tahun 2017. Badan Pusat Statistik 
Kabupaten Majalengka.

Inten, S., CCW, D. E., \& S., B. R. N. (2017). Peranan Penyuluh Pertanian

Dalam Peningkatan Pendapatan

Petani Komoditas Padi Di

Kecamatan Tanjungselor

Kabupaten Bulungan Kalimantan Utara. Jurnal Agrifor, 16(1), 103108.

Joan, A. P., Nugroho, I., \& Suwarta. (2018). Analisis Fungsi Produktivitas dan Fungsi Pendapatan Usahatani Jagung Arjuna di Desa Mulyoagung Kecamatan Dau Kabupaten Malang. Jurnal Agrika, 12(1), 8392.

Kementerian Pertanian Republik Indonesia. (2018). Luas Panen Jagung. Kementerian Pertanian Republik Indonesia.

Krisnawati, Purnaningsih, N., \& Asngari, P. (2013). Persepsi Petani Terhadap Peranan Penyuluh Pertanian di Desa Sidomulyo dan Muari, Distrik Oransbari, Kabupaten Manokwari Selatan. Jurnal Sosio Konsepsia, 3(1), 301-312.

Listiana, I., Sumardjo, Sadono, D., \& Tjiptopranoto, P. (2018). Hubungan Kapasitas Penyuluh dengan Kepuasan Petani. Jurnal Penyuluhan, 14(2), 244-256.

Lusiana, Laapo, A., \& Howara, D. (2018). Peran Penyuluh Pertanian Dalam Meningkatkan Pendapatan Usahatani Padi Sawah Di Desa Oloboju Kecamatan Sigi Biromaru Kabupaten Sigi. Jurnal Agrotekbis, 6(1), 40-47.

M, M., Syam, H., \& L, L. (2019). Peran Penyuluh Pertanian terhadap Peningkatan Kompetensi Petani dalam Aktivitas Kelompok Tani di Desa Rea Kecamatan Binuang Kabupaten Polewali Mandar. Universitas Negeri Makasar.

Muljono, P. (2007). Learning Society,
Penyuluhan dan Pembangunan Bangsa. Jurnal Penyuluhan, 3(1), 55-62.

Padillah, Purnaningsih, N., \& Sadono, D. (2018). Persepsi Petani tentang Peranan Penyuluh dalam Peningkatan Produksi Padidi Kecamatan Tabir Kabupaten Merangin Provinsi Jambi. Jurnal Penyuluhan, 14(1), 1-10.

Rahmawati, Mahludin, B., \& Bahua, M. I. (2019). Peran Kinerja Penyuluh dan Efektivitas Pelaksanaan Penyuluhan pada Program Intensifikasi Jagung. Jurnal Sosial Ekonomi Pertanian, 15(1), 56-70.

Resicha, P. (2016). Peran Penyuluh Pertanian dalam Pengembangan Kelompok Tani di Nagari Sungai Pua Kecamatan Sungai Pua Kabupaten Agam. Skripsi. Universitas Andalas.

Sadono, D. (2008). Pemberdayaan Petani Paradigma Baru Penyuluhan Pertanian di Indonesia. Jurnal Penyuluhan, 4(1), 65-74.

Santoso, R., \& Sudarmadji, H. (2013). Faktor-Faktor yang Mempengaruhi Produksi Jagung di Kabupaten Sumenep. Jurnal Pertanian Cemara, 10(1), 10-17.

Setiawan, I. (2008). Alternatif Pemberdayaan Bagi Peningkatan Kesejahteraan Petani Lahan Kering (Studi Literatur Petani Jagung Di Jawa Barat). Program Studi Agribisnis, Fakultas Pertanian, Universitas Padjadjaran.

Simamora, B. (2005). Analisis Multivariat Pemasaran. Gramedia Utama. Jakarta.

Suratiyah, K. (2006). Ilmu Usahatani. Penebar Swadaya Group. Jakarta

Tahir, A. G., \& Suddin, A. F. (2017). Analisis Pendapatan Usahatani Jagung pada Lahan Sawah dan Tegalan di Kecamatan Ulaweng, Kabupaten Bone Sulawesi Selatan. 
Jurnal Galung Tropika, 6(1), 1-11. Zulfikar, Amanah, S., \& Asngari, P. S. (2018). Persepsi Petani terhadap Kompetensi Penyuluh Pertanian
Tanaman Pangandi Kabupaten Aceh Utara. Jurnal Penyuluhan, 14(1), 159-174. 